DOI: $10.2478 / \mathrm{v} 10025-011-0007-3$

JOURNAL OF WATER

AND LAND DEVELOPMENT

J. Water Land Dev. No. 14, 2010: 83-95

\title{
Drainage system in the Kampinos National Park
}

\author{
Waldemar MIODUSZEWSKI, Zbigniew KOWALEWSKI, \\ Robert ŻURAWSKI, Justyna STANKIEWICZ
}

1) Institute of Technology and Life Sciences, Department of Water Resources, Falenty, 05-090 Raszyn, e-mail: w.mioduszewski@itep.edu.pl

\begin{abstract}
The Kampinos National Park was established to protect valuable wetlands, mainly shallow peat lands. The wetlands are subject to different kind of anthropogenic impact. The most significant is a threat caused by drainage system constructed to regulate soil moisture for agriculture purposes. The observations have shown that constant lowering of groundwater level caused degradation of organic soils and unfavourable changes of ecosystems.

The research was conducted to find some technical measures to stop ecosystem degradation and to reconstruct the natural water conditions. Most important is to implement a proper water management which would help keeping a high soil moisture. The study shows that it is necessary to build hundreds of small weirs on all ditches and rivers. The dikes should keep the spring water on the surface of the valley. The possibilities of delivery of some water from the Vistula River are discussed as well. The most important is to implement the proper water management using existing hydraulic structures.
\end{abstract}

Key words: hydraulic structure, hydrology, wetlands, national parks

\section{INTRODUCTION}

For centuries the marshes (wetlands) were treated as worthless and even harmful to human. For a long time people tried to "tame" them, i. a. by drying. Areas with high water content have been drained to produce food for the growing number of people. Drainage allowed for the intensification of production and/or acquisition of new lands that had been previously inaccessible for agriculture.

Not earlier than in the second half of the twentieth century it began to reach out to the general awareness that marsh areas are one of the most valuable ecosystems of high natural value, characterized by high biodiversity (DEMBEK, OŚWIT, 1989). It also turned out that wetlands play an important role in regulating the circulation of water in river basins and protect water quality (MICHALAK et al., 1982; MIODUSZEWSKI, 2002; OKRUSZKO, 2005). It also should be underlined that a large biological progress that has been made in agriculture led to a considerable increase 
in yields (e.g. cereal yield has increased several times over the past 50 years). The area needed for production of adequate quantities of food has decreased. Marginal landsof small agricultural value, including areas with excessive water content are, therefore, abandoned by farming. They can, and should be returned to the nature.

The main ecosystem for protection of which the Kampinoski National Park has been established is valuable natural wetlands. These marshes were and still are under various anthropogenic impacts. The most important of them seems to be drainage systems constructed for agricultural purposes.

Drained areas, adapted to agricultural production, are now protected as valuable natural wetlands. Some of them are still used by farmers as extensive meadows and pastures (ANDRZEJEWSKA, 2003; KAZIMIERSKI et al., 1995). Protected areas are still equipped with a hydro-technical equipment that, according to the original intention, was meant to adjust soil moisture to the needs of agricultural production. Change of the wetlands' function from "productive" to "natural" requires changes in water management. It is necessary to increase the level of ground water, increase moisture of organic soils and longer retention of water on the surface. On some parts of the area also agricultural needs must be taken into account.

The aim of this paper is to present the bases of water management in the Park and the possibility of using the existing hydro-technical infrastructure for the protection of natural values, and to demonstrate necessary reconstruction or construction of new facilities.

Difficulties in the implementation of the tasks arise from the ownership issues and agricultural use of wetland ecosystems. At present, permanent increase of moisture is possible mainly in the areas owned by the State Treasury and held in the administration of the KPN. On private lands soil moisture must be adapted to the use of the area. So, it seems obvious that the most precious natural areas where it is necessary to maintain a high moisture, should be repurchased as soon as possible.

\section{CHARACTERISTICS OF THE KAMPINOS NATIONAL PARK}

The Park was established in 1959 to protect wildlife and historical and cultural heritage of the Kampinos Forest. The area of the Park is 38.5 thousand ha, and the buffer zone - around 37.7 thousand ha. According to the physiographic division of the country, the Park is located entirely in the proglacial valley of the Vistula River, which occupies central part of the Warsaw Basin - a part of the Mazowiecka Plains. The direct vicinity of so large and important protected area to the capital city is rare in the world scale (Fig. 1).

The Park consists of parallel elongated dune bands alternated with marsh and swamp belts (Fig. 2). High diversity of habitats is reflected in more than 50 plant 


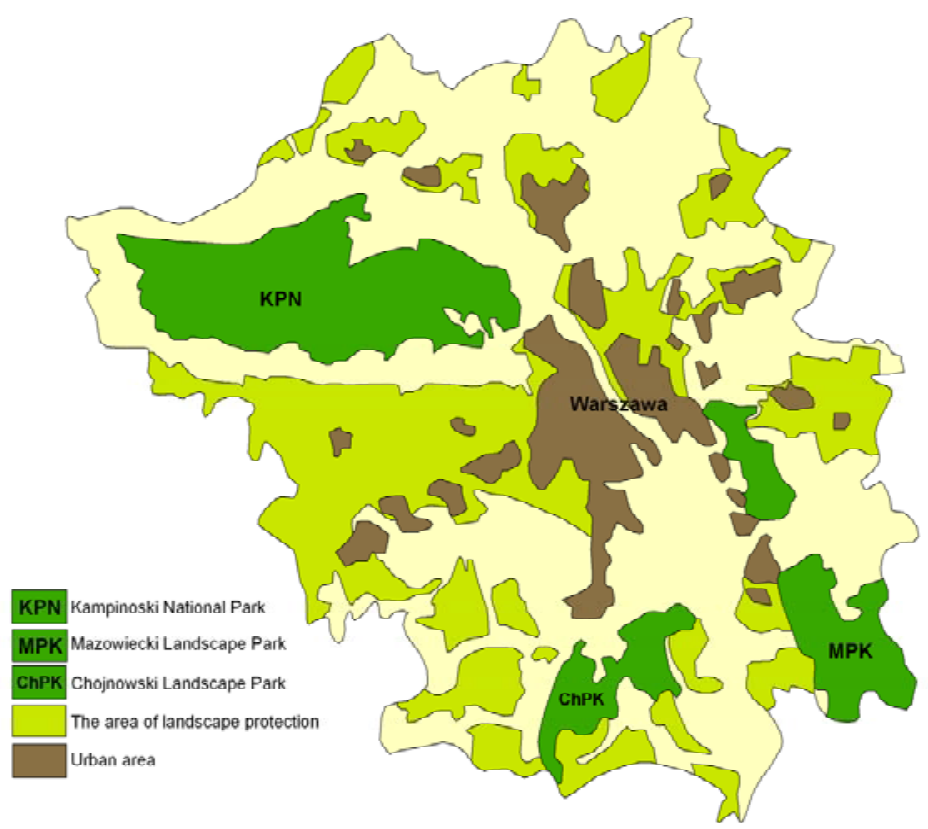

Fig. 1. Protected and urbanized areas in Warsaw (according to KRÓL, SKOLIMOWSKA-KRÓL, 2004, modified)

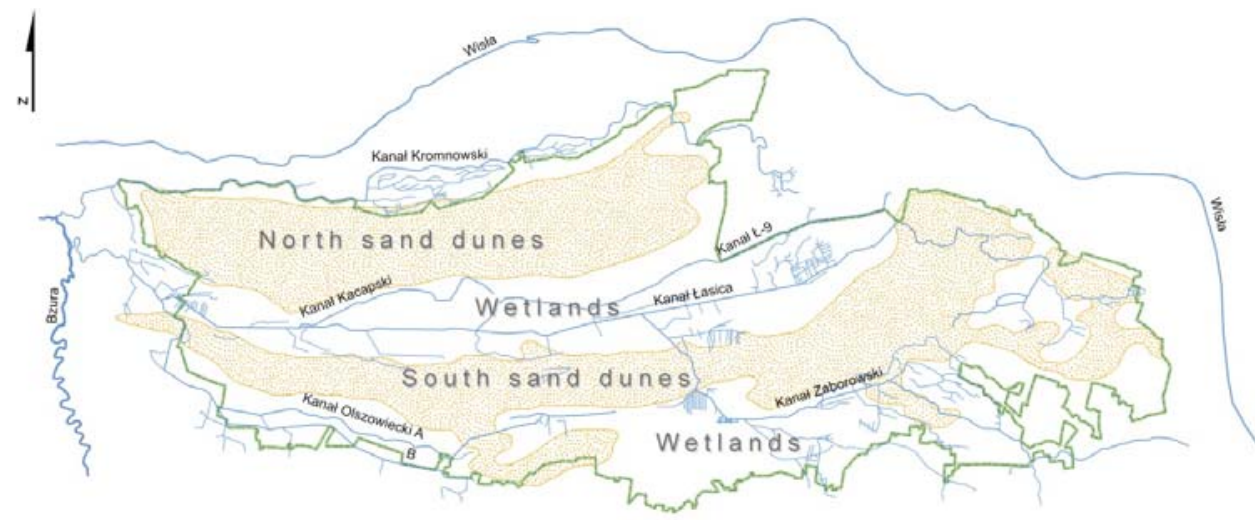

Fig. 2. Range of dune and marsh belts in the region of the Kampinos National Park

communities being formed by about 1400 species of vascular plants, 115 species of bryophytes and 146 lichen species (OKOŁÓw, 2009). Predominant (70\%) part of the Park is covered by forests, where 66 species of trees and 70 species of shrubs can be distinguished. The preservation of natural assets is determined by the condition of aquatic habitats. This particularly concerns the areas of wetlands, sensitive to water scarcity. 
The term wetlands means areas with high water content, also referred to as swamp areas, marshes or quaking bogs etc. that are permanently or temporarily under the influence of a high ground water level, reaching the surface, often flooded. In English literature they are called wetlands (Hydrogeology..., 1993; CAMPBELl, OGDEN, 1999). A number of factors determine the shape and state of wetlands' water conditions. They are generally related to climatic conditions and human activity (anthropogenic impacts).

Agriculture has long exerted a strong impact on the use of wetlands by reclamation of the area. It allowed the intensification of grassland farming and obtaining relatively high yields from former wetlands in contrast to sand dunes which, due to poor soil, had no value for agriculture. For centuries it was thought that wetlands' drainage would enable the development of agriculture in this region.

\section{THE TRANSFORMATION OF WATER CONDITIONS}

In the past, many anthropogenic and natural factors influenced the changing water conditions in the Kampinos Forest and in neighbouring areas. They were varied, and their impact was perceptible at different times, with variable intensity, mainly in the form of transition of the elements of the natural environment, especially plants.

The area of the current Park was affected by urbanization, the scale of residential development increased, a number of small factories were established. This resulted in the increased consumption of water collected mainly from underground water intakes for municipal purposes. This fact is particularly important in shaping and changing the amount of the Park's water supply from uplands.

Since 1990, an additional prominent factor influencing the water conditions in the Park has been changing climate conditions, the presence of long rainless periods, snowless winters leading to dry periods and increased loss of water resources, mainly due to the evapotranspiration of plant communities.

It can be assumed that the most significant changes in water conditions in the Park area started in the end of the eighteenth century, along with the initiation of drainage works that led to reclamation of the flooded areas. Single ditches were made to drain water as quickly as possible from local depressions and areas intended for agricultural crops. The scale of these operations was relatively small. Another reason for the changes in question was the construction of embankments of the Vistula and Bzura rivers, ultimately eliminating the flood lagoons. Even in the nineteenth century flooding of the entire area between the Vistula, Bzura and Błonska Upland was reported (e.g. floods in 1813 and 1844). The construction of embankments was completed in the middle of the twentieth century.

Significant transformations of water outflow from the region of the Park probably started around the year 1867 (CHUDZYŃSKI, 2005). Building of the Łasica 
channel started than along the route between the northern and southern strip of dunes.

The first major project of the Forest reclamation was developed in 1919-1920. This project has never been realized. The final draft approved in 1934 by the Ministry of Agriculture and Agrarian Reforms allowed for starting the field works. The project included the watershed of the Lasica River, Olszowiecki Channel and the Zaborowski Channel (TYLKO, 1950). In addition to the construction of drainage ditches also the periodic damming of water in the main courses was planned. Undertaking the drainage works was justified by difficult living conditions of rural residents in the area. It was emphasized that "the marshy meadows and pastures were overgrown with bushes and alder thickets". Even minor rains caused the immediate flooding of a significant area by waters from unregulated rivers. A poor harvest and the sour hay, even in dry years did not have any value. A small percentage of arable land islands located on the plains were flooded and there was no way of rational cultivation (TYLKO, 1950). There was also information about malaria incidents among the resident population of the Forest.

It is worth noting that even before the war it was understood that digging the deep channel of the Łasica River and Olszowiecki Channel and resulting overdrying of soils was unfavourable for agriculture. It was stated that "the soil of outstanding meadow character, plowed by individual farmers, turned to arable soils with poor structure and low efficiency. It needs rising the groundwater level". (TYLKO, 1950). As a result of the above findings, in 1938 an unrealized, complementary project was proposed to build the pumping station, near Lake Dziekanowskie with a capacity of $2.4 \mathrm{~m}^{3} \cdot \mathrm{s}^{-1}$ for supplying water from the Vistula River to the regulated Łasica Channel.

Hydro-technical equipment (rivers and weirs), bridges and culverts were largely destroyed during the World War II. Further destruction took place in 1947 as a result of flooding (break off of the Vistula embankments), particularly severe in the basin of the Lasica River and Olszowiecki Channel.

In the post-war period further steps towards the intensification of agriculture in the area, including hydrological analysis (BYCZKOWSKI et al., 1960) were undertaken. These included mainly the enlargement of river's cross-section through removal and mowing vegetation and the construction of additional drainage ditches. In the 60 s of the twentieth century several options to bring water from the Vistula River were considered. None of the variants was realized. In the 70's and 80 's of the previous century 8 damming hydraulic structures on the Lasica River were built. To some degree they considered the needs of environmental protection in the Park.

Water management issues were examined in the mid-90s of the XX century in the Plan for the Protection of the KPN. Mainly the construction of dam facilities on the Lasica River and on smaller tributaries was predicted. A few small dams slow- 
ing down the runoff water were built (STEFANIAK, 2009). The current state of the hydrographic network with damming hydraulic structures is shown in Figure 3.

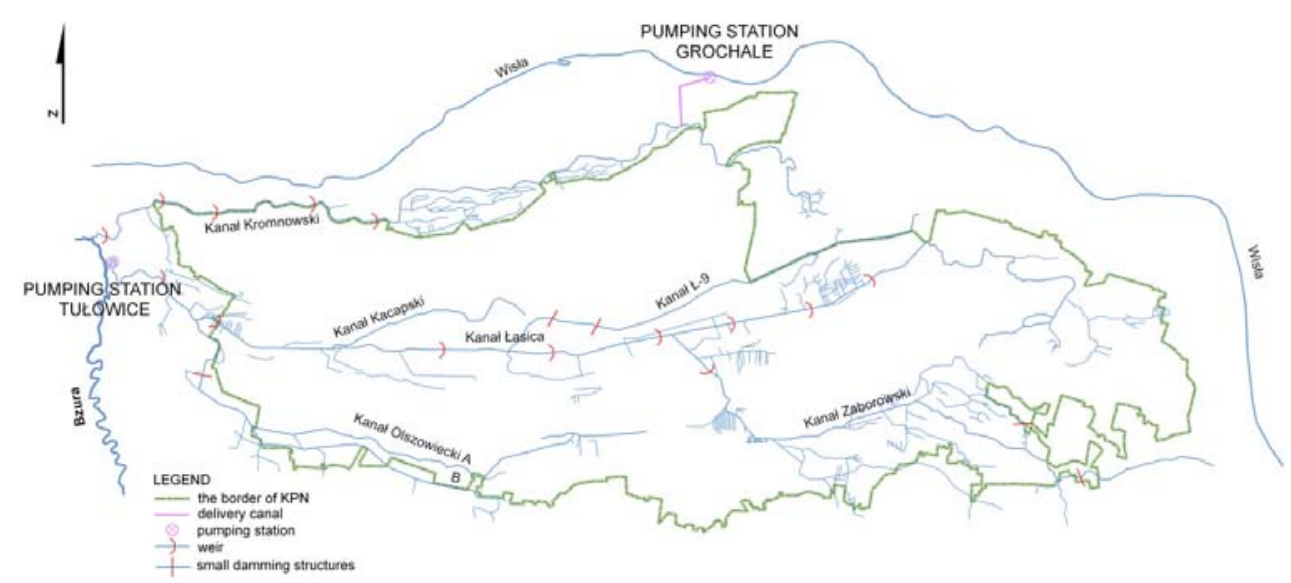

Fig. 3. The existing hydrographic network and hydrotechnical constructions in the area of the Kampinos National Park

To explain the process of water circulation in the KPN, a measurement network for surface and ground water was set up (ANDRZEJEWSKA, 2003; KAZIMIERSKI and SIKORSKA-MAYKOWSKA, 1979; KROGULEC, 2004; SOMOROWSKA, 2006).

Noteworthy, the current drainage system is highly developed and consists of the following elements:

- the main drainage channel - the Lasica River - with 8 damming hydraulic structures;

- core channels (ditches), supporting the main channel and led mainly parallel to it, namely: Olszowiecki Channel, Zaborowski Channel, channel Ł-9, Kacapski Channel;

- single small drainage ditches, draining water from the local terrain depressions;

- regular network of trenches with a span of about 100-200 m, built to drain the larger homogeneous swampy area;

- trenches located in the foot of the slope led in the valley by the slope of the plateau or dune; they intercept ground water flowing from adjacent areas;

- roadside ditches, usually of small dimensions, draining the melting water or water after increased precipitation;

This diversity of the drainage system affects the scope, method and technical capabilities of reconstruction of the primary water conditions. 


\section{ANTHROPOGENIC IMPACT ON WATER CONDITIONS IN THE KPN}

The cause of wetland degradation is usually the scarcity of water, resulting mostly from anthropogenic impact and manifesting itself by lowering of groundwater level, which leads to a reduction of soil moisture and sometimes to changes in hydrological regime of rivers. Finding possible ways of reconstruction of original water conditions requires a detailed diagnosis of current water conditions and evaluation of the reasons that resulted in the occurrence of degradation processes. There is no doubt that one of the main reasons of changes in water conditions is water drainage system. Nevertheless, it is appropriate to carry on a comprehensive examination of adverse effects that may arise from both anthropogenic and natural reasons. With respect to changes in hydrological conditions within the KPN, the following factors can be distinguished:

- cessation of flooding of the Lasica River valley due to the construction of embankments of the Vistula and Bzura rivers in the years 1948-1950. At high water levels (ice jam floods) water from the Vistula River flew to the Bzura River and then to the Lasica River valley.

- lowering of the groundwater level as a result of adjustment (channel deepening) of the Lasica River, the construction of canals and drainage ditches, including roadside ditches. Due to permeable mineral bottoms, the range of influence of the ditches can be very large.

- acceleration of the surface runoff of water that once stagnated on the surface of wetlands. As a result of the construction of ditches and levelling (unification) of the area by agrarian activities, water is quickly drained from the wetland area.

- probable lowering of water level in the Vistula River as a result of erosion processes. It is believed that within the borders of Warsawthe river channel subsided by about $1.0 \mathrm{~m}$. However, no data are available on the changes of the Vistula river channel geometry within the KPN. It has been estimated that the extent of fluctuations in water level of the Vistula River in the KPN ranges from 0.5 to $2 \mathrm{~km}$ from the river bank. It seems that the long-term (permanent) change of the water level in the Vistula can affect a much wider area. Effects of low water level in the Vistula, as well as cutting off the flood water by embankments, can be quite important factor contributing to changes in the groundwater table level. This matter has never been the subject of more detailed research and analysis.

- increasing evapotranspiration results in faster decline of shallow groundwater level during the growing season. This phenomenon may be caused by the existence of plants with large water requirements, such as trees or cane, in place of extensive meadows or sedges. Greater consumption of water is a result of the increased biomass production due to the increased habitat fertility (fertilization, deposition of nutrients from the air). It is very likely that after the lowering of 
the surface water level by drainage system, further lowering of ground water took place due to the intensification of agricultural production.

- reduced water supply to wetlands from neighbouring areas. Houses and buildings in the adjacent areas, intensification of agricultural production, drainage systems draining the agricultural land and constructions may be the cause of the smaller groundwater input to bogs. It is reflected in the measurements in piezometers located on the border of the plateau.

- reduction of water inflow to wetland depressions from the dunes. The dunes are a local small watersheds where ground water is recharged by infiltration. No information is available about the amount of infiltrating water in the dune areas and on the impact of dune afforestation on the changes in the aquifer recharge.

- lowering of the groundwater level due to the construction of underground water intakes and ponds. There are many wells in the KPN. There are no bigger intakes except the one located in the Łasica River estuary. However, there are numerous dug ponds, located usually on the border of plateaus and valleys or dunes. These small but numerous ponds reduce the water table, as they usually penetrate the less permeable layer, causing the water damming within the borders of dunes (upland). Due to the high number of small ponds, they may adversely affect water resources in micro-watersheds.

The analysis presented above clearly demonstrates the complex nature of hydrology in the area of the KPN. When developing the plan to reconstruct the natural water conditions, i.e. those present in the area many years ago, it should be kept in mind that the observed degradation and lowering of groundwater level could have many different reasons. Therefore, technical and non-technical measures that have been proposed should be differentiated.

\section{THE ROLE OF THE EXISTING INFRASTRUCTURE FOR WATER MANAGEMENT IN THE KPN}

The existing hydro-technical infrastructure consists mainly of drainage ditches, which do not allow for rational water management. Constructions that can be used to improve moisture conditions are only 8 weirs in the Lasica River, one weir in the Zaborowski channel and several culverts ( 2 in channel $Ł-9,1$ in the Olszowiecki channel and 2 in Zaborowski channel).

Each of the weirs in the Lasica River has a water permit issued by the governor, which sets a maximum level of damming, with the assumption that it can be lowered during the haymaking. It is also assumed that during the winter season and high water episodes the culvert will be open. These are typical assumptions adopted in the planning of water management for agricultural production (grasslands). Protection of wetlands usually requires constant maintenance of high damming, also in winter and spring, under the condition that water stagnation on the 
surface of wetlands does not result in loss of natural values. Hence, it is important to define in the restoration plans the areas that can be flooded, and those which need only maintaining a high level of ground water. It should be noted that in practice, the implementation of technical devices allowing the separation of these two areas is very difficult.

Lowering the dam during haymaking sometimes poses a risk of lowering the groundwater table and often of insufficient amounts of water to refill the layer.

The existing constructions have the closures in a form of sliding flaps. It is very simple and effective device for streams with substantial flows. At low flow rates, which is the case in the Lasica River, the closure of this type does not work as lifting the flap by even a few inches totally eliminates the damming effect. It is difficult or even impossible to adjust the position of high water table. Very often unintentional or malicious lifting of the flap by unauthorized persons may cause irreversible loss of water.

The existing small valves also have a closure that does not meet the requirements of water protection, being often not tight enough.

The next stage of development of hydro-technical equipment is the action carried out by the KPN to limit the outflow. Low weirs $(10-30 \mathrm{~cm})$ on selected water courses and small dikes on the surface runoff routes have been built. These are simple, wood-earth constructions effectively restricting the outflow of water. They are very valuable due to the improvement of local moisture conditions. A significant drawback of these buildings is the poor construction that cannot resist the influence of strong current. After the passage of high waters, the constructions are often destroyed and need renovation. The problem is that they are rebuilt during the dry periods when no water is available, and destroyed at a time when there are opportunities for water collection.

\section{BASIC ACTIVITIES FOR THE IMPROVEMENT OF MOISTURE CONDITIONS}

Presented overview of the causes of changes in the water conditions in the KPN shows that the restoration of original hydrological conditions is unlikely or even impossible. This would require the backfilling of most rivers, including the main channel - Lasica. There is lack of sufficient knowledge about the "original conditions", also the reasons of wetlands degradation (changes of water conditions) are not fully known. Ownership, financial and technical issues are also the obstacles. However, there is a real chance to prevent adverse changes in hydrology and to increase the level of ground water. This should be a long-term process, which would cover both the technical and non-technical measures related to the development and use of wetlands and adjacent areas. It should also implement the proper 
methods for water resources management. Technical measures for water conditions improvement may include a large variety of different works like:

- limiting the draining nature of small streams through filling (liquidation) of small watercourses and construction of permanent, low weirs on individual courses conducted along drainage depressions and in the so-called "slopeside" and "roadside" trenches;

- reduction of surface runoff from dune areas by building low dikes that would separate the existing gorges and ravines;

- construction of dikes along the river in sites with clear land depression in the valley (this applies to the Łasica and large channels). The aim of such constructions is to prevent a rapid outflow of snowmelt water from the valley after lowering the water level in the river (channel);

- construction of culverts in ditches (drainage facilities, regular networks of ditches) for the regulation of water level in areas used for agriculture, conducting the irrigation with respect to the needs of agriculture and environment;

- reduction of drainage character of the Łasica and channels requires rebuilding the existing weirs in the Lasica to allow year-round water damming, including the replacement of vent equipment, which will allow for precise regulation of water level. Most likely this will be necessary to install additional dams on the Łasica, mainly with fixed weirs;

- reduction of the cross-section and/or making the river to meander at selected channels in order to reduce the longitudinal gradient and to increase the water level in the riverbed;

- supplementation of water by its delivery from the Vistula, if it appears necessary during the renaturisation works.

It should be emphasized that the actions presented above result from the current state of knowledge with regard to the natural conditions and existing hydro -technical infrastructure. Location and selection of the construction types and methods of regeneration of water conditions depend largely on the actual needs of the natural environment and the technical capabilities.

During the renaturisation works some corrections after obtaining the results of monitoring data are inevitable. It is also necessary to supplement the existing measuring devices, particularly to assess changes in flow and local changes in groundwater level.

When analyzing possible use of technical measures it was assumed that, in areas where the natural environment is the main water user, human intervention (maintenance services) in the water flow regulation should be minimized. Therefore, equipment and constructions (e.g. barrages with constant weir) which do not require ongoing adjustment were usually suggested. Constructions with closures are recommended for agriculturally used areas or when the stream drains water 
from a larger area with high flow variability. However, in this case it is appropriate to install the closures for automatic regulation of the upper water level.

Non-technical measures affecting both directly and indirectly the water cycle are also important. Such measures include:

- changing the ownership through purchase of private lands by the park, which would enable more effective implementation of technical activities,

- changes in the use and development of wetlands and adjacent areas, ensuring the protection of water resources (reduction of evapotranspiration, increase of groundwater recharge),

- developing the concept of water usage different from the existing one, adapted to the technical actions and changing climate conditions,

- improved monitoring of water conditions (measurements of water levels and flows),

- organization of the department responsible for implementation of the principles of water management in the Park and its buffer zone, supervised by the Director of the KPN.

\section{SUMMARY}

Improvement of moisture conditions in the Kampinos National Park, which is necessary for the protection of valuable natural assets of wetlands, requires technical and non-technical actions. New rules of water management are needed. The existing hydro-technical infrastructure has been designed and operated mainly with regard to the needs of agriculture. It is essential to rebuild the existing infrastructure and to develop new rules of water usage. The implementation of small constructions restricting the outflow of water from various types of small ditches, field depressions, etc. is urgently needed. However, these constructions must be sufficiently robust and adapted to pass high waters that occur mainly during the spring thaw. Purposefulness of water delivery from the Vistula River to maintain flows in the Lasica River and to recharge ground waters should also be considered.

Technical measures should be complemented by relevant non-technical activities. This applies particularly to the appropriate management and use of both the KPN lands and the surrounding areas. This is especially true for the use that does not lead to a reduction of evapotranspiration and groundwater recharge.

\section{REFERENCES}

1. ANDRZEJEwSKa A., 2003. Physiography and nature monitoring in the Kampinos National Park. Ecohydrology and Hydrobiology, 3: 247-254.

2. BYCZKOWSKI A., DĘBSKı K., KICIŃSKI T., 1960. Bilans wodny rzeki Łasicy (Water balance of Łasica River). Gospodarka Wodna, 9: 412-414. 
3. CAmpBell C.S., Ogden M.H., 1999. Constructed wetlands in the sustainable landscape. John Wiley \& Sons, Inc.: 1-270.

4. ChUdzYŃSKi M., 2005. Puszcza Kampinoska w XIX w. i na początku XX w. W: Kampinoski Park Narodowy. (The Kampinos Forest in the XIX and begining of XX centuary. In: The Kampinos National Park). T. 3 cz. 1. Pr. zbior. Red. P. Matusiak. Izabelin, Wydaw. KPN: 351-455.

5. DEMBEK W., OśwIT J., 1989. Niektóre aspekty roli mokradeł w gospodarce wodnej krajobrazu. (Some aspects of the role of wetlands in the water management). Wiadomości Melioracyjne i Łąkarskie 8/9: $150-161$.

6. GutRY-KorycKa M., Michna I., Macioch A., 2009. Raport z realizacji Podzadania 3, Narzędzia 3 Zadanie B2 i B3 wykonanego w ramach Projektu PL0268. (The Report of topic 3, tool 3 - task B2, B3 of the Project PL0268) Warszawa, UW maszynopis.

7. Hydrogeology of wetlands, 1993. Journal of Hydrology vol. 141: 1-272.

8. Kazimierski B., Pilichowska-Kazimierska E., Sikorska-Maykowska M., 1995. Studium warunków wodnych. W: Plan ochrony Kampinoskiego Parku Narodowego. (The study of water conditions. In: Plane of the protection of the Kampinos National Park). Warszawa, Narodowa Fundacja Ochrony Środowiska: 1-100.

9. KAZIMIERSKI B., SiKORSKA-MAYKOWSKA M., 1979. Koncepcja organizacji sieci obserwacyjnej wód podziemnych wybranej jednostki hydrogeologicznej. (The concept of observation net of groundwater level for chosen hydrographic area). Gospodarka Wodna, 9: 269-272.

10. KROGULEC E., 2004. Ocena podatności wód podziemnych na zanieczyszczenia w dolinie rzecznej na podstawie przesłanek hydrodynamicznych. (The analysis of water quality in the river valley). Warszawa, Wydaw. UW: 1-140.

11. Michalak J., Sikorska-Maykowska M., KaZimierski B., 1982. Obniżenie poziomu wód gruntowych tarasu przyczyną degradacji środowiska Kampinoskiego Parku Narodowego. (Decreasing of groundwater table as a reason of environmental degradation in the Kampinos National Park). Gospodarka Wodna, 6: 75-78.

12. MioduszewsKi W. (red.), 2002. Gospodarowanie wodą w łęgowej dolinie Górnej Narwi. (Water management in the Narew Valley). Falenty, Wydaw. IMUZ.

13. ОкоŁów G., 2009. Kampinoski Park Narodowy. (Kampinos National Park). Izabelin, Wydaw. KPN: $1-20$

14. OKRUSZKo T., 2005. Kryteria hydrologiczne w ochronie mokradeł. (The hydrological criteria in protection of wetlands). Rozprawy Naukowe i Monografie. Warszawa, SGGW: 1-146.

15. SOMOROwSKa U., 2006. Wpływ stanu retencji podziemnej na proces odpływu w zlewni nizinnej. (The influence of groundwater retention on the process of water outflow from the river basin). Warszawa, Wydaw. UW: 1-150.

16. StefaniaK P., 2009. Walka o wodę. (The struggle for water). Puszcza Kampinoska, 2 (62): 1-24.

17. Tylko M., 1950. Stan i potrzeby melioracji w Puszczy Kampinoskiej. (The condition and need for drainage system in the Kampinos Forest). Gospodarka Wodna, 6: 264-268.

\section{STRESZCZENIE}

\section{System odwadniający w Kampinoskim Parku Narodowym}

\section{Słowa kluczowe: budowle wodne, hydrologia, mokradta, parki narodowe}

Podstawowym ekosystemem, do ochrony którego został powołany Kampinoski Park Narodowy, są cenne przyrodniczo mokradła. Mokradła te znajdowały i znajdują się pod presją różnych oddziaływań antropogenicznych. Najistotniej- 
szym z nich wydają się melioracyjne systemy odwadniające, wykonane w przeszłości na potrzeby intensyfikacji produkcji rolniczej na terenach odwadnianych. Wybudowane kanały, wyposażone w urządzenia hydrotechniczne, w pierwotnym zamiarze miały służyć usprawnieniu gospodarowania wodą i dostosowaniu uwilgotnienia gleb do wymagań upraw rolnych. Zakładana zmiana funkcji obszarów mokradłowych z ,produkcyjnych” na ,przyrodnicze” wymaga również zmian w pierwotnych założeniach gospodarowania wodą. Niezbędne jest podwyższenie poziomu wód gruntowych, zwiększenie uwilgotnienia gleb organicznych oraz dłuższe przetrzymywanie wody na powierzchni terenu.

Celem niniejszej pracy jest przedstawienie przyczyn zmian warunków wodnych obszaru Parku, historii przekształceń sieci hydrograficznej, aktualnego sposobu gospodarowania wodą i na tej podstawie określenie możliwości wykorzystania istniejącej infrastruktury wodnej w celu dostosowania do nowych zadań, tj. warunków wodnych ze względu na ochronę walorów przyrodniczych obszarów bagiennych.

Reviewers:

Prof. Janusz Kubrak

Prof. Krzysztof Nyc 